\title{
OBITUARY
}

\section{SIR PERCIVAL DAVID}

Percival Victor David Ezekiel David was born at Bombay on 21 July 1892 and died at his home in London on 9 October 1964. He was educated at Elphinstone College and Bombay University, and succeeded his father, Sir Sassoon David, the first baronet, in 1926. He had all the qualities that go to the making of a collector, percipience, visual memory, ingenuity, and tirelessness in pursuit of the quarry. To these he added something rarer among collectors, a scholarly instinct and discipline. Visiting China on business in 1927 he was impressed by the tradition of art connoisseurship he found there. He determined to pursue it and to build up a porcelain collection on the lines of the Imperial Collection in the Forbidden City in Peking. The old social order was breaking up, and those were days of unexampled opportunity to a buyer with knowledge, judgment, and an ample fortune. His second ambition was to bring to London a great exhibition of Chinese art, with contributions of outstanding treasures from the Peking palace and the principal museums and private collections of Europe and America. His third, formulated in later years, was to establish a great centre of Chinese art studies in the University of London, which should cultivate, through the appreciation of the Chinese artistic genius, a deeper understanding and a greater respect for China in the Western world.

In the first two projects he was encouraged by that prince of collectors, the late George Eumorfopoulos, founder-president of the Oriental Ceramic Society. The Society had been started in 1921, and was at first a coterie of twelve amateurs and museum curators who met at each others' houses to exchange views and discuss specimens. To this exclusive circle David was admitted in 1930, after his first visits to the Far East. In 1934 the Society was opened to a wider membership, and now has a roll of over 800 and an international reputation.

David's first contribution to the literature of Chinese ceramics was made in 1929, an article in the short-lived quarterly, Eastern Art, entitled ' Some notes on pi-sê yao'. This was a closely reasoned argument for the identification of certain bowls of Yüeh Chou type as the pi-sê yao, the ware of private or reserved colour, of the princes of $\mathrm{Wu}$ and Yüeh, in the Five Dynasties period. It was followed the next year by 'The Shōsō-in', in the Transactions of the Japan Society, an exhaustive account of the history and contents of the famous imperial treasury at Nara. David had visited the treasury in two successive years at the time of the annual three weeks' 'airing', and had been given opportunities, rarely if ever accorded to a foreign expert, of examining and handling the objects.

From now on the Transactions of the Oriental Ceramic Society became the principal vehicle of his writings - notes, introductions to exhibition catalogues, and several long papers of lasting value. Vol. x (1931-2) carried an article on 'The Shōsō-in pottery' in which he marshalled the evidence supporting the 


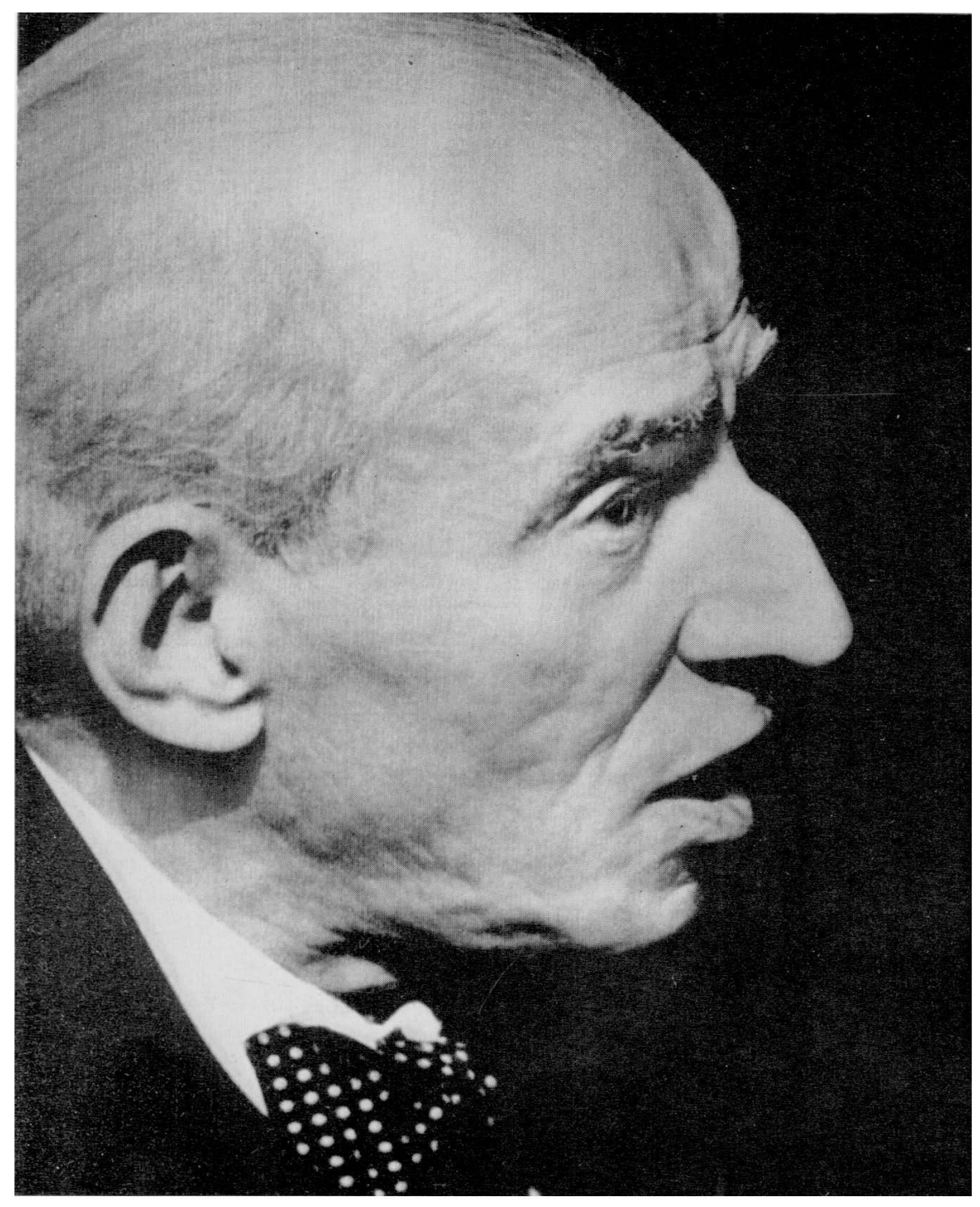

Sir Percival David

BSOAS. XXVIII] 
rival theories of Chinese and Japanese origins of the san $t^{\prime}$ 'ai vessels in the Nara treasury, and came down emphatically on the side of the former. Vol. XI (1933-4) contains 'Chinese porcelain at Constantinople', in which he collaborated with R. L. Hobson in an account of their inspection of the enormous accumulation of Yüan and Ming porcelains in the Topkapı Sarayı. A long paper in the same volume, 'Hsiang and his album', caused a sensation. The album referred to is the $L i$ tai ming $t z^{6} \breve{u} t^{6} u p^{6} u$ ' Illustrated description of noteworthy ceramics of different dynasties ', purporting to be a manuscript notebook of the well-known sixteenth-century artist and connoisseur, Hsiang Yüan-pien. It turned up in Peking in 1885, when it was purchased by Dr. Stephen Bushell, at that time physician to the British Legation, and was discussed by him before the Peking Oriental Society. It was eventually published by the Clarendon Press in 1908, in a beautiful edition, with facsimile reproductions of the coloured drawings and an English translation and notes by Bushell. It quickly acquired a reputation as a kind of ceramist's bible, and in 1931 a still more splendid edition appeared in Peking from the pens of Kuo Pao-ch'ang and J. C. Ferguson. Great importance was claimed for the album by Bushell and others, because it was the only early descriptive catalogue known, and the pictures were supposed to provide valuable data as to the form and colour of Sung porcelains by a Ming connoisseur of note.

Uneasiness had, however, been felt by some as to the genuineness of the work because of an error in an artist's name and an anachronism in the text, while some of the objects illustrated seemed to be ceramically impossible, and the pictures showed such errors as white-glazed interiors of early monochromes. David discovered that many of the illustrations were exact copies of line drawings, mostly of bronzes, in the Sung catalogues of antiquities Po ku $t^{6} u l u$ and $K^{\varsigma}$ ao $k u t^{\varsigma} u$, published more than three centuries before the alleged date of Hsiang's album. He concluded that if there ever had been such an album, the water-colour drawings and parts of the original text had been lost, and that the losses had been ' made good' by some antiquarian into whose hands the remains had fallen. The coup de grâce was delivered in 1936 by Paul Pelliot in an article in T'oung Pao entitled ' Le prétendu album de porcelaines de Hiang Yuan-pien ', in which he reached the conclusion that the whole work was an elaborate forgery.

David's most important contribution to the Transactions was his 'Commentary on Ju ware', a long paper in Vol. xIv (1936-7), in which he laid the foundations for the identification of the rare imperial $\mathrm{Ju}$ ware, the product of kilns in operation for the short period from 1107 to 1127 . The only considerable group of this ware outside the Chinese national collections is in the Percival David Foundation. His last work, an annotated translation of the Ko ku yao lun, was fortunately completed and in the press before his final illness.

His name is associated with two other literary enterprises which he sponsored, financed, and cared for at all stages of their production. The first is the catalogue of his own collection in 1934, The catalogue of the Chinese pottery and 
porcelain in the collection of Sir Percival David, by R. L. Hobson. This is remarkable both as a work of scholarship and an example of book production, a superb folio volume of 230 pages and 180 plates mostly in colour, each a masterpiece of the printer's craft and of a quality and facsimile accuracy rarely equalled to-day, after 30 years' 'progress' in colour-printing. The other work is a definitive edition of the 'Travels of Marco Polo', for which he engaged the services of Professors Pelliot and A. C. Moule. It was inspired by David's discovery of an unknown Latin manuscript of a large part of the Polo narrative in the chapter library at Toledo. Moule's share of the task, published in two volumes, was the transcription of the Latin codex, and an English translation of the FrancoItalian text in the Bibliothèque Nationale at Paris, incorporating additional and variant passages from all the other known manuscripts, including that of Toledo. The third and fourth volumes comprise 900 quarto pages of notes by Pelliot, published posthumously under the auspices of the Académie des Inscriptions et Belles-Lettres.

In all such undertakings David displayed consistently certain traits of character which his associates came to recognize and respect. The first was steadfastness and patience in the pursuit of a course to what he had decided was a necessary or desirable end. To this he added a keen appreciation of quality, whether in a pot or a book or a man ; a readiness to pay a high price for quality, and for supreme quality a very high price indeed, if necessary ; and an exceptional flair for finding ' the man for the job' as collaborator, craftsman, or servant. He had little use for the second-rate, and certainly no disposition to pay for it.

The achievement by which he is best remembered by those casually interested in Chinese art is the 'great exhibition' of 1935-6 at the Royal Academy, one of the most successful, educationally and financially, ever staged at Burlington House. It is difficult to appreciate nowadays the weight of conservatism in China and of apathy in Britain that had to be overcome, before such a plan could be brought to fruition. David enlisted the support and eventually the enthusiasm of heads of state and their ministers, senior government officials, ambassadors, patrons of the arts, and the leading scholars of Europe, Asia, and America. Was the Academy concerned at the expense involved? Then ample guarantees would be forthcoming. Were the Chinese anxious for the safety of their national treasures on the long voyage ? Then the Admiralty would provide a cruiser to transport them. No obstacles were allowed to impede the progress of the plan, and the result was a revelation to the West of the full splendour of the artistic tradition of China and an inspiration to students to explore it in depth.

The same pertinacity was apparent in David's pursuit of his third ambitionto found a centre of Chinese art studies in our University. It began with the provision by him of funds for a temporary lectureship at the School of Oriental Studies in 1931. The results were so encouraging that the Universities' China Committee provided the salary for a Chair of Chinese Art and Archaeology 
from the Boxer Indemnity Fund. The University appointed the late Professor W. P. Yetts, under whom an active department was soon organized, the first of its kind in the world, with courses of instruction leading to degrees and diplomas. The war and subsequent events in China have sadly hindered these studies, but such calamities could not deflect David from his purpose. He offered his incomparable collection of ceramics and his library to the University on conditions which he considered necessary for their use by students and the public. The conditions were not of a kind to be instantly accepted by any university, but after somewhat protracted negotiations agreement was reached. Much of the credit for this was due to Dame Lillian Penson, who was ViceChancellor at the time. The house at 53 Gordon Square was set aside to accommodate the gift, converted and equipped under the able and energetic supervision of the late Professor Eve Edwards, and opened to the public as the Percival David Foundation of Chinese Art on 10 June 1952. Unless or until the Chinese national collections become generally accessible again, it remains the most important centre of Chinese ceramic studies in the world. Its staff and students have made considerable contributions to the advancement of these studies and provided research material for other scholars, while there are few foreign visitors interested in the subject who pass through London without paying the Foundation a visit.

He was a great traveller. The outbreak of war found him in Shanghai, where he was interned by the Japanese and contracted the illness which progressively reduced him to physical helplessness. In the last ten years most of his waking hours were spent in a wheelchair. This did not prevent numerous journeys to the continent of Europe, the United States, Formosa, Japan, and Russia. His last trip was to Stockholm in 1963, for the opening of the new Museum of Far Eastern Antiquities by the King of Sweden.

It is not surprising that the demands he made upon himself and others sometimes put severe strains on their patience, but he had a large circle of friends and he was touchingly grateful for their help in his projects and for any attention that his disabilities imposed on them. Percy David will be remembered as a charming host and a delightful raconteur. He became a legendary figure in his own lifetime, and will remain one wherever the arts and antiquities of China are loved and studied. 